\title{
Rosa e Estrela
}

\author{
Jorge Bento
}

Permitam-me V. Exas. que situe esta homenagem no contexto que a determinou.

As nações não prescindem de santos e heróis.

Sempre e em todos os tempos precisam de homens que funcionem como arquétipos e exemplos a seguir. De homens que se arranquem do chão da mediania e não deixem morrer nos demais a coragem, o destemor e a ousadia. Sem eles os povos e as nações não se fazem e não se sustentam. Quando não existem, há que inventá-los. Não importa em que domínio, nem a sua proveniência ou estrato social. Importa sim tê-los para investir neles a recriação de símbolos e mitos do passado, a confiança no presente e a esperança na invenção do futuro. Para se transcenderem e arrastarem os outros para a transcendência. Muitos desses heróis - tantos e tantos! - são criados no desporto, como poetas desmedidos do corpo, do esforço e do suor, da dor e da vontade, da ingenuidade e da ilusão. Os seus feitos não são apenas seus, nem apenas desportivos; são façanhas de todo um País e bandeira ondulante do pulsar das suas forças e anseios. O herói desportivo transporta nos seus ombros o fardo de traumas e angústias, de derrotas e humilhações, de sonhos e esperanças de grandeza e dignidade de um povo. Ergue nas asas do seu triunfo o orgulho adormecido da sua gente e faz irromper no seu grito de vitória a voz reprimida dos seus concidadãos. Porém, muitas vezes e tal como tantos outros heróis, é um herói tragicamente humano. Um herói que, após os fugidios dias de glória, vê empalidecer a sua luz e dá consigo a conhecer penosos e escuros dias de tragédia, esquecido e ignorado. $\mathrm{O}$ herói que fez a festa e a alegria do povo naufraga num oceano de amarguras. Abandonado à sua sorte. De resto o herói trágico está no centro da existência.
Não é tanto o sacrificado, mas é sobretudo a disponibilidade para o sacrifício que merece a admiração em todos os povos e culturas.

Rosa Mota foi e é uma heroína desportiva. Não uma heroína trágica e esquecida, mas uma heroína que continua viva na nossa gratidão e admiração, no nosso apreço e afecto. Foi para lhe dizer isto que aqui nos reunimos. Para lhe dizer que continua a ser Rosa e Estrela.

Mais, uma Faculdade de Ciências do Desporto cumpre a sua missão ao serviço de um desporto melhor, entendido este como instrumento de realização de um mundo com o mesmo sentido. Logo é natural que admire e tome como seus cúmplices aqueles que na organização e na prática do desporto emergem como paladinos daquela ideia. Rosa Mota figura por mérito próprio entre os protagonistas de louvor e eleição. Era, pois, da mais elementar justiça que viéssemos aqui dizer-lhe isto e afirmar que dela recebemos inspiração para manter fidelidade à defesa de princípios e valores imanentes ao desporto. Que o seu exemplo de conduta e sucesso limpos nos encoraja a denunciar e verberar atropelos à verdade desportiva. Essencialmente porque os valores adquiridos e cultivados no palco desportivo não se confinam a esse espaço; transitam para além dele, para um quadro mais lato e abrangente. Não se ensinam e aprendem apenas para terem valimento no desporto, mas essencialmente para vigorarem na vida, para lhe traçarem rumos, alargarem os horizontes e acrescentarem metas e meios de as alcançar. Para dar expressão máxima ao bom e verdadeiro, ao belo e sublime. É de campeões iluminados por valores deste jaez que a vida e o desporto precisam. De campeões - como Rosa Mota - que não se contentem em vencer uma 
vez, mas que saibam merecer, pela exemplaridade do seu civismo, a vitória pela vida fora. Que procedam bem não tanto por obrigação, mas sim pelo simples prazer de agirem assim e pelo cuidado de não degradarem a imagem e a memória que deixam de si. Decidimos vir aqui homenagear Rosa Mota em nome dos valores e para significar que não nos podemos calar perante o agravo à dignidade e grandeza, à inteireza e idoneidade, à elevação e exaltação da condição humana que se escondem por detrás de todos os instigadores e consumidores de substâncias dopantes. Porque entendemos o desporto como um meio de visar mais alto, de elevar os olhos e a alma para a transcendência do azul do céu, para que este se aproxime de nós e venha tingir da mesma cor as nossas mãos e os nossos gestos. Porque não se pode pactuar com a fraude, com a mentira, com a falsidade, com o descaso, com o abastardamento, com a rasteirice, com a esperteza saloia que recorrem ao doping para iludir a conformidade a um estatuto de menoridade.

Tínhamos esta homenagem em mente desde o ano passado, mas sentimos ainda mais a sua pertinência e acerto quando, há poucos meses, vimos um futebolista acusado de consumo de doping ser recebido em clima de desagravo e de heroicização, com a FPF a entregar-lhe uma placa como se fosse uma condecoração. Quando vimos as montagens na televisão, na rádio e nos jornais para dar publicidade às mais despudoradas tentativas de o ilibar e de incriminar os técnicos e métodos que o apanharam nas malhas da ilicitude, sentimos que a falta de ética, na sua versão mais perversa e moderna, tinha já roído a coluna vertebral do velho Portugal probo, austero e honrado. Sentimos que a questão do doping faz parte da questão mais geral dos valores, que o seu consumo se filia na mentalidade anti-valores que tomou conta do mundo, que a luta contra o doping se insere na luta que urge travar denodadamente em defesa dos princípios e valores.

Nós os professores sentimos sobretudo que a educação está a conhecer um falhanço rotundo. O que está em causa não é só a verdade desportiva, é um mundo de verdade em primeiro lugar, porque é do contexto mais geral do grande mundo que todos os pequenos mundos (como é o caso do desporto) e a sua configuração brotam. Ou se está do lado de um mundo que se pauta por valores éticos e estéticos, ou se alinha com um mundo que se forja na batotice, na trafulhice, na fealdade e negrume de emoções e sentimentos. Se não nos importamos com o doping no desporto e com a adulteração da verdade desportiva, então é mister que cuidemos de educar os nossos filhos e netos de outra forma e com outra intenção. É imperioso que lhes ensinemos, desde a mais tenra idade, as artimanhas e safadezas que garantem a sobrevivência e o sucesso nesta selva da fraude e da mentira. É obrigatório que os ensinemos e estimulemos a mentir, a copiar, a ludibriar, a roubar, a usurpar aquilo que é dos outros, a não ser sérios, frontais, transparentes e verdadeiros. Requer-se que não lhes ensinemos hábitos e regras de trabalho, que não lhes inculquemos uma consciência moral de respeito e lealdade aos outros, de observância de padrões de comportamento que consagram o triunfo da consciência livre e moral sobre a baixeza animal. Requerse que não os preparemos para uma vida que apenas existe na mente dos visionários e que tenhamos a capacidade e o estômago de resistir ao vómito que é introduzi-los em práticas que significam o regresso aos primórdios da civilização e afirmam o seu contrário. Se é este o legado "cultural" e "civilizacional" que devemos transmitir aos nossos filhos, então ponhamos cobro à educação e a todas as formas de a realizar. Porque a educação tem uma profunda e essencial implicação ética e axiológica, isto é, ou se pauta por valores ou não é educação alguma, mas antes o seu contrário. E o mesmo se aplica ao desporto que é no seu cerne uma entidade voltada para a espiritualização das forças físicas do homem, para o domínio dos instintos, para a edificação de uma condição humana, eminentemente axiológica, por cima de uma natureza animal movida pelos impulsos mais baixos e arcaicos. É um meio de realizar o homem como pessoa moral que pauta a sua vida por uma consciência de valores e que à luz dela concretiza a liberdade. O desporto pode naturalmente ser instrumentalizado para outras finalidades pertinentes e legítimas, pode gerar diversas externalidades, mas sempre circunscrito a um horizonte de valores, porque fora dele transforma-se em mera exercitação animal, livre da supervisão da logos moral.

Em suma a tomada de posição a favor ou contra o doping insere-se neste quadro de opções. Tenho 
muita pena, mas não se pode ter sol na eira e chuva no nabal. Aceitar o doping como um meio de alcançar sucesso no desporto corresponde a engrossar as fileiras da cruzada contra os valores no contexto mais geral da vida. É fazer da rapina uma bandeira e erigir os vigaristas e oportunistas em heróis e tomar como artolas, burros e ingénuos os que persistem em construir a sua vida e imagem com a pedra da decência, da verticalidade e da honradez. É rir-se de nós, mesmo na nossa cara, por ainda não termos desistido de falar nestas coisas. Por continuarmos a pensar, dizer, escrever, proclamar e fundamentar que vale a pena navegar contra a corrente da vergonha e da devassidão. Por persistirmos em balizar os caminhos da vida com sonhos, ideais e utopias. Por nos mantermos fieis à crença de que os caminhos do homem que conduzem à felicidade se desviam do abismo da escuridão e são iluminados por raios de uma luz fortíssima a que chamamos rectidão. Por querermos que os nossos filhos e netos dêem seguimento à tarefa de consagrar o triunfo da verdade. Sim, os tartufos, os venais, os medíocres, os amorais e (toda a corja de) vendidos ao poder do dinheiro riem-se de nós. Resta-nos resistir com a convicção de que, na história da humanidade, as horas negras acabam sempre por ficar para trás e que o mal nunca vence; limita-se a passar rasteiras e a atrasar o bem na senda que o leva para o futuro.
Senhoras e senhores,

Caros amigos:

O exemplo de Rosa Mota encoraja-nos a cerrar fileiras, a não desistir desta luta. Porque a excelência e as medalhas de ouro da sua vida foram sempre conseguidas no campo da verdade desportiva. Ela foi, é e será sempre Rosa e Estrela. Um arquétipo e um modelo a dizer-nos a toda a hora que o desporto faz parte da luta contra a ideologia da impotência que insinua que na vida não há nada para fazer, que não podemos fazer nada por nós, que não somos sujeitos principais da nossa construção, que nos devemos omitir e entregar nos braços de um destino de derrotados e vencidos da existência.

Rosa Mota fez-se a si própria, demonstrando que nós somos o que fazemos de nós. Provou à evidência que as pessoas, as instituições e os países podem transcender as condições de origem e a magreza de recursos e alcançar a excelência. Desde que tenham alma, coração e vontade para vencer as maratonas e as distâncias mais longas que são as que estão dentro de nós. E podem fazê-lo e obter sucesso de maneira limpa, de cara lavada, sem manchar a honra e o carácter, sem se sujar na lama da leviandade, da desconfiança e suspeição. Por isso Rosa Mota é um arquétipo de cidadania e um modelo de comportamento desportivo. Bem haja pelas alegrias e emoções que nos proporcionou e pela lição de vida que nos legou! Para sempre Rosa! 